ISSN 1678-3921

Journal homepage: www.embrapa.br/pab

For manuscript submission and journal contents, access: www.scielo.br/pab

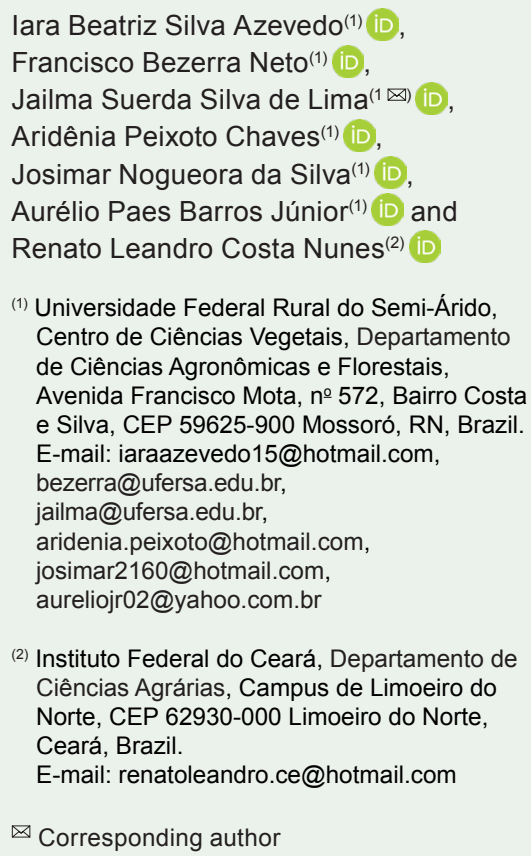

(2) Instituto Federal do Ceará, Departamento de Ciências Agrárias, Campus de Limoeiro do Norte, CEP 62930-000 Limoeiro do Norte, Ceará, Brazil.

E-mail: renatoleandro.ce@hotmail.com

$\bowtie$ Corresponding author

Received

December 21, 2019

Accepted

November 05, 2020

How to cite

AZEVEDO, I.B.S.; BEZERRA NETO, F.; LIMA,

J.S.S de; CHAVES, A.P.; SILVA, J.N. da;

BARROS JÚNIOR, A.P.; NUNES, R.L.C.. Agroeconomic efficiency of immature cowpea-radish intercropping systems in semiarid environment. Pesquisa Agropecuária Brasileira, v.56, e01666, 2021. DOI: https://doi.org/10.1590/ S1678-3921.pab2021.v56.1666.

\section{Agro-economic efficiency of immature cowpea-radish intercropping systems in semiarid environment}

\begin{abstract}
The objective of this work was to evaluate the agro-economic efficiency of immature cowpea-radish intercropping systems in a semiarid environment in Brazil. The experiments were carried out in two cropping seasons, in a randomized complete block design with four replicates. The treatments consisted of a $4 \times 2$ factorial arrangement for the combination of four cowpea (Vigna unguiculata) cultivars (BRS Tumucumaque, BRS Cauamé, BRS Guariba, and BRS Itaim) and two radish (Raphanus sativus) cultivars (Crimson Gigante and Zapp). The agro-economic indices - system productivity index (SPI), land equivalent coefficient (LEC), and monetary equivalent ratio (MER) - were obtained using single plots of each cultivar in each block. 'BRS Tumucumaque' and 'BRS Guariba' showed the highest productivity of immature cowpea pods, and 'Crimson Gigante' showed the highest yield of marketable radish roots. The cultivation of either 'BRS Tumucumaque' or 'BRS Guariba' cowpea with 'Crimson Gigante' radish provides a greater agro-economy efficiency and sustainability for immature cowpea-radish intercropping.
\end{abstract}

Index terms: Vigna unguiculata, Raphanus sativus, Calotropis procera, productivity, sustainability.

\section{Eficiência agroeconômica de sistemas consorciados de feijão-caupi verde e rabanete em ambiente semiárido}

\begin{abstract}
Resumo - O objetivo deste trabalho foi avaliar a eficiência agroeconômica de sistemas consorciados de feijão-caupi verde e rabanete, em ambiente semiárido brasileiro. Os experimentos foram realizados em duas safras agrícolas, em delineamento de blocos ao acaso, com quatro repetições. Os tratamentos consistiram de um arranjo fatorial $4 \times 2$, para a combinação de quatro cultivares de feijão-caupi (Vigna unguiculata) (BRS Tumucumaque, BRS Cauamé, BRS Guariba e BRS Itaim) com duas cultivares de rabanete (Raphanus sativus) (Crimson Gigante e Zapp). Os índices agroeconômicos - índice de produtividade do sistema (IPS), coeficiente equivalente de terra (CET) e razão equivalente monetária (REM) - foram obtidos em parcelas de cultivo solteiro de cada cultivar, em cada bloco. 'BRS Tumucumaque' e 'BRS Guariba' apresentaram a maior produtividade de vagens verdes de feijão-caupi, e 'Crimson Gigante' mostrou a maior produtividade de raízes comerciais de rabanete. O cultivo do feijão-caupi 'BRS Tumucumaque' ou 'BRS Guariba' com o rabanete 'Crimson Gigante' proporciona maior eficiência agroeconômica e sustentabilidade ao consórcio de feijão-caupi verde com rabanete.
\end{abstract}

Termos para indexação: Vigna unguiculata, Raphanus sativus, Calotropis procera, produtividade, sustentabilidade. 


\section{Introduction}

The intercropping system has been one of the main cultivation practices contributing to improve the sustainability of agricultural production and increasing crop yields (Oliveira et al., 2010; Damasceno et al., 2016). Its efficiency depends directly on the crops and cultivar combinations involved (Silva et al., 2017; Bezerra Neto et al., 2019). Thus, it is necessary that the crops be considered companions, that is, formed of mutually beneficial plants when grown together, and that, in the choice of these crops and cultivars, the possibility of some complementarity between them be observed. This is possible when the species have distinct ecological niches, and the use of light, water, and nutrient absorption are maximized in more than one crop in a given area and time.

When intercropped, crop cultivars should be highly plastic and should yield reasonably stable yields on a wide range of production factors, such as cropping seasons, cropping systems, plant populations, spatial arrangements, fertilization levels, etc. (Seran \& Brintha, 2010; Gebru, 2015). Intercropping allows flexibility to vary the levels of these production factors. However, when crops are grown in association, interactions occur between the component species, evidencing a response of a species modified by the presence of other ones. This interaction can also promote the conservation of soil quality, biodiversity, pest control, or crop resilience (Kremen \& Miles, 2012; Jarecki et al., 2018; Hunt et al., 2019). Competition in crop blends is therefore twice that of the monocultivation, since inter- and intraspecific competition occur (Doubi et al., 2016). Therefore, the success of a crop mixture will depend on the choice of the right cultivars.

Cowpea and radish are two companion crops of economic and nutritional value that can complement each other in an intercropping system because they have different plant architectures and root systems (Pereira et al., 2016; Chaves et al., 2020). Thus, an intercropping system between these crops has been recognized as a potentially beneficial system of agricultural production, as it increases the total yield of crops per unit of land per unit of time, as well as it increases the diversity of products, reduces the economic risks of the producer, and helps to efficiently and judiciously use the land, labor, and other environmental resources of the rural land (Nunes et al., 2018).
The intercropping system has been little studied in relation to the evaluation of cultivar combinations suitable for this cultivation system, since the studies focus mostly on the evaluation of cultivars for the monocropping, hindering the understanding of the behavior of these genotypes in an association system (Porto et al., 2011). With the appearance of new cowpea and radish cultivars adapted to conditions of high temperature and ample solar radiation of the Brazilian Northeast, it is essential to obtain comparative data on the behavior and performance of these materials in intercropping systems, as this type of production system is widely used in the producing regions of food crops. These materials were developed for monocropping systems, thus, studying the ability of interspecific combination of these materials is of paramount importance to attain high production and agro-economic efficiency in intercropping systems (Costa et al., 2017).

Some attempts have been made in evaluation trials of vegetable cultivars in intercropping systems, aiming to understand the behavior of these materials in association, and their efficiency in proportioning promising agro-economic intercropping systems. Silva-De Lima et al. (2010) evaluated the behavior of bicropping arugula cultivars intercropped with carrot cultivars; these authors registered a greater agronomicbiological efficiency with the combination of Brasília carrot and Cultivada arugula, as well as the highest economic efficiency when combining the Brasília carrot with Folha Larga arugula.

However, Costa et al. (2017) combined cultivars of both cowpea and carrot in intercropping system, in a semiarid environment in Northeastern Brazil, and concluded that the intercropped system that used BRS Guariba cowpea and Alvorada carrot cultivars attained greater agronomic-biological efficiency, whereas the system with combination of BRS Tumucumaque cowpea with Brasília carrot cultivars achieved the highest economic efficiency.

The objective of this work was to evaluate the agro-economic efficiency of immature cowpea-radish intercropping system in a semiarid environment.

\section{Materials and Methods}

Two experiments were carried out from May to December of 2016 and 2017 cropping seasons, at Rafael 
Fernandes Experimental Farm, of the Universidade Federal Rural do Semi-Árido (Ufersa), located in Lagoinha district, a rural area in the municipality of Mossoró ( $5^{\circ} 03^{\prime} 37^{\prime \prime S}, 37^{\circ} 23^{\prime} 50^{\prime \prime} \mathrm{W}$, at $18 \mathrm{~m}$ altitude), in the state of Rio Grande do Norte, Brazil.

The soil of the experimental area is classified as Latossolo Vermelho-Amarelo distrófico (Santos et al., 2013), which corresponds to Oxisol. Soil samples were collected at $0-20 \mathrm{~cm}$ soil depths and showed the characteristics below described for 2016 and 2017 cropping seasons.

In 2016, the soil analysis showed the following chemical characteristics: $\mathrm{pH}$ (water), 8.20; organic matter (OM), $3.64 \mathrm{~g} \mathrm{~kg}^{-1} ; \mathrm{N}, 0.51 \mathrm{~g} \mathrm{~kg}^{-1} ; \mathrm{P}, 10.3$ $\mathrm{mg} \mathrm{dm}{ }^{-3} ; \mathrm{K}^{+}, 57.2 \mathrm{mg} \mathrm{dm}^{-3} ; \mathrm{Ca}^{+2}, 0.60 \mathrm{cmol}_{\mathrm{c}} \mathrm{dm}^{-3} ; \mathrm{Mg}^{+2}$, $0.60 \mathrm{cmol}_{\mathrm{c}} \mathrm{dm}^{-3} ; \mathrm{Na}^{2+}, 11.6 \mathrm{mg} \mathrm{dm}{ }^{-3}$; soil electrical conductivity (EC), $1.77 \mathrm{ds} \mathrm{m}^{-1}$. In 2017, the soil analysis showed the following characteristics: $\mathrm{pH}$ (water), 6.60; $\mathrm{OM}, 3.65 \mathrm{~g} \mathrm{~kg}^{-1} ; \mathrm{N}, 0.42 \mathrm{~g} \mathrm{~kg}^{-1} ; \mathrm{P}, 34.2 \mathrm{mg} \mathrm{dm}{ }^{-3} ; \mathrm{K}^{+}, 69.2$ $\mathrm{mg} \mathrm{dm}{ }^{-3} ; \mathrm{Ca}^{+2}, 3.10 \mathrm{cmol}_{\mathrm{c}} \mathrm{dm}^{-3} ; \mathrm{Mg}^{+2}, 0.80 \mathrm{cmol}_{\mathrm{c}} \mathrm{dm}^{-3}$; $\mathrm{Na}^{2+}, 19.0 \mathrm{mg} \mathrm{dm}^{-3}$; EC, $0.10 \mathrm{ds} \mathrm{m}^{-1}$.

The climate of the region according to the KöppenGeiger's classification is 'BShw', dry and very hot, with rainy season in the summer delaying to autumn, with $27.4^{\circ} \mathrm{C}$ mean annual temperature, a quite irregular annual precipitation, with average $673.9 \mathrm{~mm}$, and $68.9 \%$ relative humidity (Alvares et al., 2013). Mean temperatures and relative humidity during the experimental period are presented in Figure 1.

The experiments were carried out in a randomized complete block design with four replicates. The treatments consisted of a $4 \times 2$ factorial arrangement for the combination of four cowpea cultivars (BRS Tumucumaque, BRS Cauamé, BRS Guariba, and BRS Itaim) with two radish cultivars (Crimson Gigante and Zapp). These cultivars are recommended by research for monocultivation in the semiarid condition of Northeast of Brazil (Costa et al., 2017). The first three cowpea cultivars have a semi-erect plant and indeterminate growth habit, and BRS Itaim has an erect plant and determined growth habit. All cowpea cultivars have a crop cycle between 65 and 70 days. Crimson Gigante radish has a high plant and a crop cycle between 30 and 35 days, while Zapp radish has a medium plant and a crop cycle between 25 and 30 days. In each block, the studied cultivars were planted in single plots as additional treatments to attain the agro-economic indices.
The crop association was established in alternate strips of the component cultures in the proportion of $50 \%$ of the area for cowpea, and $50 \%$ of the area for radish. Each plot was made up of four rows of cowpea alternated with four rows of radish, flanked by two rows of radish on one side, and two rows of cowpea on the other side, thus constituting the lateral borders. In each block, each cultivar was planted in a single plot in its optimum population density, recommended to attain the efficiency indices of the intercropping.

The experimental plot of the intercropping had 3.60 $\mathrm{m}^{2}$ total area, with $2.00 \mathrm{~m}^{2}$ harvest area. The spacings used for the intercrop were $0.25 \times 0.10 \mathrm{~m}$ for cowpea, containing 72 plants, and $0.25 \times 0.04 \mathrm{~m}$ for radish, with 180 plants per plot. For cowpea monocropping, the experimental plot had the same dimensions as the plot used in the intercrop $\left(3.60 \mathrm{~m}^{2}\right)$, with $2.00 \mathrm{~m}^{2}$ harvest area, differing only for row spacing, that was of $0.50 \times 0.10 \mathrm{~m}$, with 72 plants per plot, at 200,000 plants ha ${ }^{-1}$ population density (Santos et al., 2018). The radish monocropping had $1.44 \mathrm{~m}^{2}$ total area, with $0.80 \mathrm{~m}^{2}$ harvest area, and $0.20 \mathrm{x} 0.10 \mathrm{~m}$ spacing, totaling 72 plants per plot, at 500,000 plants ha $^{-1}$ population density (Batista et al., 2013). The population densities of both radish and cowpea were the same in both cropping systems.

The soil preparation of the experimental area consisted of one harrowing followed by lifting of the beds by a mechanized way, with the aid of a bed shaper.

In the planting area, a solarization was carried out in pre-planting, with transparent plastic for 30 days, to combat nematodes and phytoparasites at $0-10 \mathrm{~cm}$ soil depths, especially Meloidogyne spp. (Favacho et al., 2017).

For the fertilization of the experiments, green manure from Calotropis procera was applied. This species is spontaneous to the native vegetation of Caatinga biome, near the experimental area, and it was collected before the beginning of flowering. The plant was crushed in a conventional forage machine, to obtain fragmented particles with size around 2.0 to 3.0 $\mathrm{cm}$ that were dehydrated under sunlight, until reaching approximately 10\% moisture was achieved. Samples of this material were sent for analysis of their chemical composition, which showed the characteristics described as follows. In the 2016 cropping season: $\mathrm{N}$, $18.40 \mathrm{~g} \mathrm{~kg}^{-1} ; \mathrm{P}, 3.14 \mathrm{~g} \mathrm{~kg}^{-1} ; \mathrm{K}^{+}, 4.5 \mathrm{~g} \mathrm{~kg}^{-1} ; \mathrm{Ca}^{2+}, 16.30$ $\mathrm{g} \mathrm{kg}^{-1}$, and $\mathrm{Mg}^{2+}, 13.35 \mathrm{~g} \mathrm{~kg}^{-1}$. In 2017: $\mathrm{N}, 15.30 \mathrm{~g} \mathrm{~kg}^{-1}$; 
$\mathrm{P}, 0.66 \mathrm{~g} \mathrm{~kg}^{-1} ; \mathrm{K}^{+}, 25.60 \mathrm{~g} \mathrm{~kg}^{-1} ; \mathrm{Ca}^{2+}, 8.60 \mathrm{~g} \mathrm{~kg}^{-1}$, and $\mathrm{Mg}^{2+}, 8.80 \mathrm{~g} \mathrm{~kg}^{-1}$.

The crop fertilization was performed in all plots, using C. procera as green manure incorporated into
0-20 $\mathrm{cm}$ soil depths with the help of hoes, 20 days before planting (Linhares et al., 2011). The amounts of green manure used were established according to the research recommendation for each system (Batista
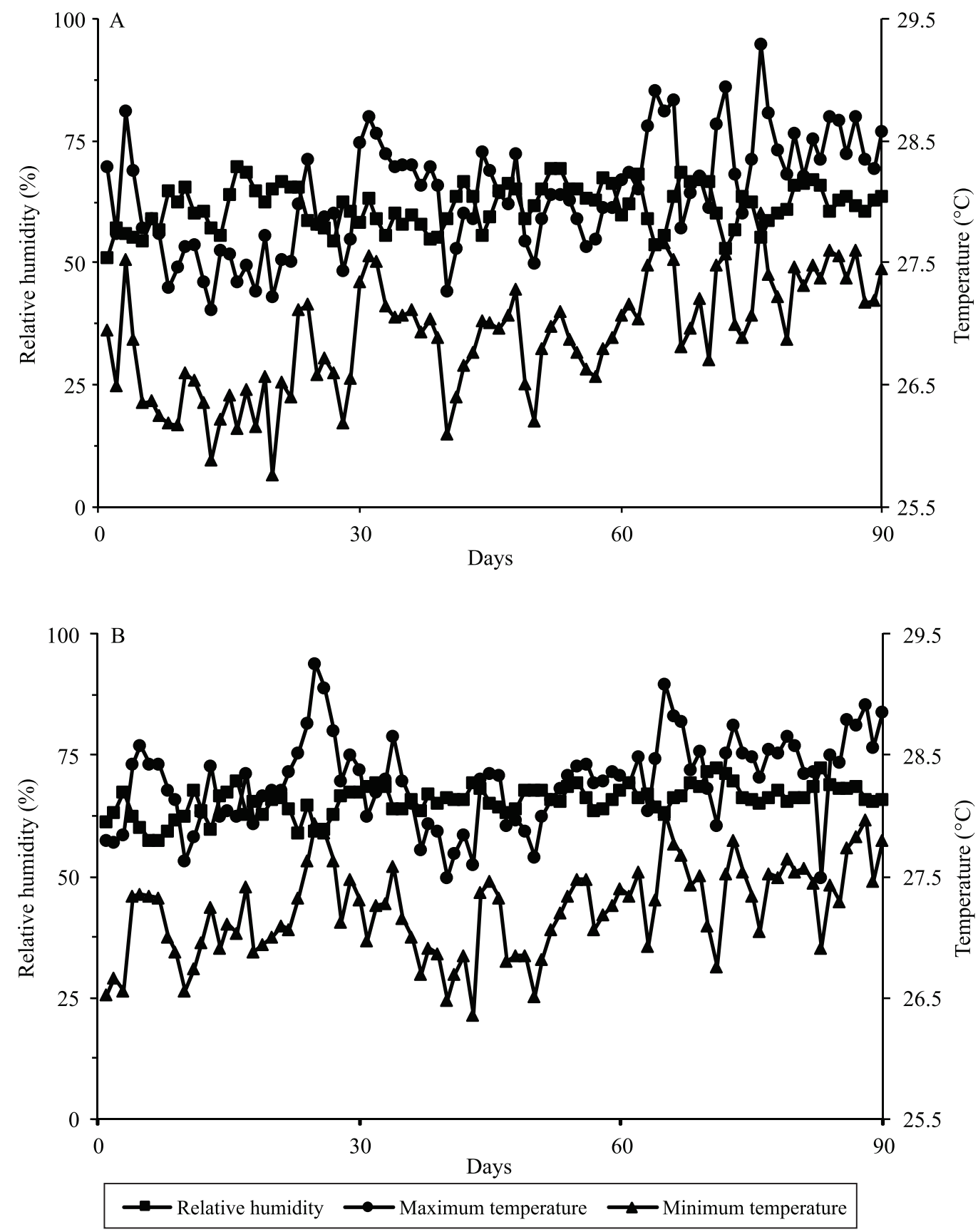

Figure 1. Mean temperatures and relative humidity during the 2016 and 2017 cropping seasons, in Lagoinha district of the municipality of Mossoró, in the state of Rio Grande do Norte, Brazil, provided by Instituto Nacional de Meteorologia (INMET). 
et al., 2013; Pereira et al., 2016). In the intercropping system, $50.01 \mathrm{Mg} \mathrm{ha}^{-1}$ of $C$. procera (Pereira et al., 2016) was applied, while in the single crop system incorporated amounts were 59.4 and $17.5 \mathrm{Mg} \mathrm{ha}^{-1}$ for cowpea and radish, respectively (Batista et al., 2013).

Cowpea and radish were sown on the same day, September 5, 2016 and October 20, 2017, in holes approximately $2 \mathrm{~cm}$ deep, using 2 to 3 seed per hole for both cowpea and radish. The thinning of cowpea and radish occurred at 10 and 8 days after sowing, respectively. During the cycle, manual weedings were made in both cultivations and heap was applied to radish whenever necessary. Harvests occurred in different dates due according to crop cycles. Radish harvest was performed 30 days after planting. Cowpea harvest had its beginning 60 days after planting, and it was carried out for another four harvests in the period of 15 days, thus totaling the cowpea cycle of 75 days.

The evaluated characteristics of radish were: plant height, fresh weight of shoots, productivity of total and commercial roots, and productivity of scrap roots. The evaluated characteristics of cowpea were: immature pod length, and productivity of immature pods and grains. The agro-economic indices evaluated in the intercropping systems were: system productivity index (SPI), land equivalent coefficient (LEC), and monetary equivalent ratio (MER).

The SPI was expressed by the following formula (Poddar et al., 2017):

$$
\mathrm{SPI}=\left[\left(\mathrm{Y}_{\mathrm{r}} / \mathrm{Y}_{\mathrm{c}}\right) \times \mathrm{Y}_{\mathrm{cr}}\right]+\mathrm{Y}_{\mathrm{rc}},
$$

in which: $Y_{r}$ and $Y_{c}$ represent the productivity of radish commercial roots, and the productivity of immature cowpea grains in monocrops, respectively; $\mathrm{Y}_{\mathrm{cr}}$ is the immature grain productivity of cowpea intercropped with radish; and $Y_{\mathrm{rc}}$ is the productivity of commercial roots of radish intercropped with cowpea. The SPI $\left(\mathrm{Mg} \mathrm{ha}^{-1}\right)$ main advantage is that it standardizes the productivity of the secondary crop (cowpea) in relation to the main crop (radish).

LEC was calculated by the expression used by Adekunle et al. (2014) as

$$
\mathrm{LEC}=\mathrm{LER}_{\mathrm{r}} \times \mathrm{LER}_{\mathrm{c}} \text {, }
$$

in which $L_{E R}$ and $L R_{c}$ represent the partial land equivalent ratio of radish and cowpea, respectively. For two crops in an intercropping system, the minimum production coefficient is $0.25(25 \%)$, which shows a productive advantage of the association when the value of LEC exceeds 0.25 .

The monetary equivalent ratio (MER) was determined by the expression used by Afe \& Atanda (2015) as

$$
\operatorname{MER}=\left(\mathrm{GI}_{\mathrm{rc}}+\mathrm{GI}_{\mathrm{cr}}\right) / \mathrm{GI}_{\mathrm{r}},
$$

in which: $\mathrm{GI}_{\mathrm{rc}}$ is the gross income of radish intercropped with cowpea; $\mathrm{GI}_{\mathrm{cr}}$ is the gross income of cowpea intercropping with radish; $\mathrm{GI}_{\mathrm{r}}$ is the highest gross income in monoculture $r$ in comparison with the culture $\mathrm{c}$. The MER index measures the economic superiority (or non-superiority) of intercropping over the most economic monocrop.

A univariate analysis of variance of the randomized complete block design in factorial arrangement was performed for the characteristics and indices determined for the intercrops. A joint analysis of the two cropping seasons was performed for all evaluated variables, using the Sisvar software (Ferreira, 2011). The Tukey's test, at 5\% probability, was used to compare the means among tested cultivars, cropping seasons, and systems.

\section{Results and Discussion}

There were interactions between cropping seasons and radish cultivars for the productivities of total and commercial roots and the productivity of scrap roots. Partitioning the cropping seasons within each intercropped radish cultivar, the 2017 cropping season was superior to the 2016 cropping season, for these three variables, for both radish Crimson Gigante and Zapp cultivars (Table 1). This result can be associated with the soil fertility and the probable mineralization of the incorporated material, both referring to the second season, which made it radish culture available. Potassium is among the nutrients influencing the productive characteristics of radish cultivation and it is required in large amounts (Oliveira et al., 2014), which is mainly needed for root development (Islam et al., 2011). According to the soil chemical analyses, great amount of potassium $\left(\mathrm{K}^{+}\right)$was observed in the soil and in the material incorporated in the 2017 cropping season.

In 2017, radish cultivars differed within each cropping season for the productivity of total and scrap roots, and Zapp showed a higher productivity than Crimson Gigante. This result is due, in part, to 
intraspecific competition of cultivar that influences the amount of scrap roots and, consequently, the total productivity of radish roots. The performance of a cultivar may be related to a greater or lower competition for the soil's environmental resources (Nunes et al., 2018). In commercial root productivity, the radish cultivars showed similar behavior in both cropping seasons (Azevedo, 2018).

There were interactions between cropping seasons and cropping systems (Table 1). Partitioning the cropping seasons within each cropping system, 2017 differed from 2016 for intercropping, whereas, for monoculture, the result was the reverse, as the 2016 cropping season was superior to the 2017 for the productivity of total and commercial roots, and no difference was observed between seasons for the productivity of radish scrap roots. Concerning the cropping systems within each cropping season, it was observed that the productivity of radish roots in monoculture was higher than that of intercropping in the 2016 cropping season, and lower than that of intercropping in the 2017 cropping season. The distinct performance observed in the cropping systems may have resulted from the efficiency in the use of the available natural resources, in different situations, mainly in the 2017 cropping season, as it has shown by the intercropping system.

Interactions between cropping seasons and radish cultivars in monoculture were observed in the productivity of radish total and commercial roots (Table 1). Partitioning cropping seasons within each radish cultivar, the 2016 season was superior to 2017 for total and commercial roots yields of Crimson Gigante, while Zapp showed no significant difference between the cropping seasons.

Concerning each cultivar in monoculture within each cropping season, Crimson Gigante radish showed higher productivity of total and commercial roots than Zapp, in the 2016 cropping season. However, Zapp radish showed a higher productivity of total roots than Crimson Gigante, in the 2017 cropping season (Table 1). The productivity of Zapp cultivar in the 2017 cropping season is indicative of how much it needs an input of nutrients, to meet its nutritional demand, considering the chemical analyses of soil and material incorporated in this harvest. Similar behavior among radish cultivars was observed in the 2017 cropping season in the commercial root productivity (Azevedo, 2018).

Table 1. Mean values for plant height (PH), fresh mass of the shoots (FMS), productivity of total (PTR) and commercial roots (PCR), and productivity of scrap roots (PSR) of radish (Raphanus sativus) cultivars intercropped with different cowpea (Vigna unguiculata) cultivars, in 2016 and 2017 cropping seasons, and of radish cultivars in monoculture, and interaction effect between treatment-factors on some of these variables ${ }^{(1)}$.

\begin{tabular}{|c|c|c|c|c|c|c|c|c|}
\hline Treatment & $\mathrm{PH}(\mathrm{cm})$ & FMS $\left(\mathrm{Mg} \mathrm{ha}^{-1}\right)$ & \multicolumn{2}{|c|}{$\operatorname{PTR}\left(\mathrm{Mg} \mathrm{ha}^{-1}\right)$} & \multicolumn{2}{|c|}{$\operatorname{PCR}\left(\mathrm{Mg} \mathrm{ha}^{-1}\right)$} & \multicolumn{2}{|c|}{$\operatorname{PSR}\left(\mathrm{Mg} \mathrm{ha}^{-1}\right)$} \\
\hline \multicolumn{9}{|l|}{ Cowpea cultivars in intercrop } \\
\hline BRS Tumucumaque & $19.72 \mathrm{~A}$ & $7.23 \mathrm{~A}$ & \multicolumn{2}{|c|}{$9.95 \mathrm{~A}$} & \multicolumn{2}{|c|}{$8.13 \mathrm{~A}$} & \multicolumn{2}{|c|}{$1.82 \mathrm{~A}$} \\
\hline BRS Cauamé & $17.54 \mathrm{~B}$ & $5.77 \mathrm{~B}$ & \multicolumn{2}{|c|}{$8.72 \mathrm{~B}$} & \multicolumn{2}{|c|}{$7.22 \mathrm{~B}$} & \multicolumn{2}{|c|}{$1.50 \mathrm{~A}$} \\
\hline BRS Guariba & $18.23 \mathrm{~A}$ & $6.02 \mathrm{~A}$ & \multicolumn{2}{|c|}{$9.66 \mathrm{~A}$} & \multicolumn{2}{|c|}{$7.80 \mathrm{~A}$} & \multicolumn{2}{|c|}{$1.86 \mathrm{~A}$} \\
\hline BRS Itaim & $17.31 \mathrm{~B}$ & $5.30 \mathrm{~B}$ & \multicolumn{2}{|c|}{$8.30 \mathrm{~B}$} & \multicolumn{2}{|c|}{$6.62 \mathrm{~B}$} & \multicolumn{2}{|c|}{$1.68 \mathrm{~A}$} \\
\hline Radish cultivars in intercrop & & & Season 2016 & Season 2017 & Season 2016 & Season 2017 & Season 2016 & Season 2017 \\
\hline Crimson Gigante & $19.95 \mathrm{~A}$ & $7.15 \mathrm{~A}$ & $4.86 \mathrm{bA}$ & $12.15 \mathrm{aB}$ & $4.32 \mathrm{bA}$ & $10.38 \mathrm{aA}$ & $0.53 \mathrm{bA}$ & $1.78 \mathrm{aB}$ \\
\hline Zapp & $16.45 \mathrm{~B}$ & $5.01 \mathrm{~B}$ & $4.52 \mathrm{bA}$ & $15.10 \mathrm{aA}$ & $3.52 \mathrm{bA}$ & $11.55 \mathrm{aA}$ & $1.00 \mathrm{bA}$ & $3.55 \mathrm{aA}$ \\
\hline \multicolumn{9}{|l|}{ Cropping seasons } \\
\hline 2016 & $18.82 \mathrm{~A}$ & $6.30 \mathrm{~A}$ & - & - & - & - & - & - \\
\hline 2017 & $15.59 \mathrm{~B}$ & $5.26 \mathrm{~B}$ & - & - & - & - & - & - \\
\hline Cropping systems & & & Season 2016 & Season 2017 & Season 2016 & Season 2017 & Season 2016 & Season 2017 \\
\hline Intercropping & $18.20 \mathrm{~A}$ & $6.08 \mathrm{~A}$ & $4.69 \mathrm{bB}$ & $13.63 \mathrm{aA}$ & $3.92 \mathrm{bB}$ & $10.96 \mathrm{aA}$ & $0.77 \mathrm{bB}$ & $2.66 \mathrm{aA}$ \\
\hline Monoculture & $13.22 \mathrm{~B}$ & 4.60B & $9.62 \mathrm{aA}$ & $5.89 \mathrm{bB}$ & $7.51 \mathrm{aA}$ & $4.48 \mathrm{bB}$ & $1.69 \mathrm{aA}$ & $1.41 \mathrm{aB}$ \\
\hline \multicolumn{9}{|l|}{ Radish cultivars in monoculture } \\
\hline Crimson Gigante & $14.46 \mathrm{~A}$ & $5.35 \mathrm{~A}$ & $10.40 \mathrm{aA}$ & $4.74 \mathrm{bB}$ & $8.81 \mathrm{aA}$ & $3.85 \mathrm{bA}$ & & $4 \mathrm{~A}$ \\
\hline Zapp & $11.98 \mathrm{~B}$ & $3.84 \mathrm{~A}$ & 7.98aB & $7.04 \mathrm{aA}$ & $6.20 \mathrm{aB}$ & $5.11 \mathrm{aA}$ & & $6 \mathrm{~A}$ \\
\hline
\end{tabular}

${ }^{(1)}$ Means followed by equal letters, lowercases in the lines and uppercases in the columns, do not differ by Tukey's test, at $5 \%$ probability. 
However, significant differences between the cropping seasons were observed for plant height and fresh shoot weight of radish, whose highest mean values were recorded in the 2016 season (Table 1). There were also significant differences between the radish cultivars, for plant height and fresh shoot weight, for which Crimson Gigante showed higher values than Zapp. These results can be related mainly to the morphological characteristics of Crimson Gigante cultivar that shows large, cylindrical, and ovate leaves, which may have a larger leaf area in the conversion of solar energy into chemical energy, for the synthesis of organic compounds, resulting in higher height and higher fresh shoot weight. As it can be observed, Crimson Gigante seems to be much better adapted to the region than Zapp cultivar.

There was a significant difference between the cowpea cultivars, in the intercropping system with radish, for plant height, fresh shoot weight, and total and commercial root radish yields, in which the BRS Tumucumaque and BRS Guariba cowpea stood out, since they were more competitive when intercropped with radish (Table 1). This result is an indicative that these two cultivars were the ones that exerted less interspecific competition with radish.
Significant interactions were observed for radish yields between cropping seasons and radish cultivars in intercrop, as well as between cropping seasons and cropping systems, and between cropping seasons and radish cultivars in monoculture (Table 1). These interactions confirm the complex pattern of the types of competition between radish and cowpea cultivars, when influenced by the climatic characteristics of the cropping seasons and by the commercial radish cultivars. The Crimson Gigante and Zapp radish cultivars intercropped with cowpea had in average 16.1 and $33.2 \%$ more commercial productivity in their monocultures in the two cropping seasons. However, for the productivity of scrap roots, Crimson Gigante and Zapp cultivars had 13.6 and $23.2 \%$ of the total root productivity, that is, a percentage of commercial roots of 86.4 and $76.8 \%$ in the intercropping with cowpea. High-quality roots in the intercropping with cowpea is an indication that there was no negative effect of the competition types either within or between the associated crops.

Interactions between cropping seasons and cowpea cultivars in intercrop were observed for the length of immature pods and the productivity of immature pods and grains (Table 2). Partitioning the cropping

Table 2. Mean values for length of immature pods (LIP), productivity of immature pods (PIP) and productivity of immature grains (PIG) in the cropping seasons, cowpea ((Vigna unguiculata)) cultivars in intercrop and monoculture, and in intercropping with radish (Raphanus sativus) cultivars and monocropping systems ${ }^{(1)}$.

\begin{tabular}{|c|c|c|c|c|c|c|}
\hline \multirow[t]{2}{*}{ Treatment } & \multicolumn{2}{|c|}{$\operatorname{LIP}\left(\mathrm{Mg} \mathrm{ha}^{-1}\right)$} & \multicolumn{2}{|c|}{ PIP $\left(\mathrm{Mg} \mathrm{ha}^{-1}\right)$} & \multicolumn{2}{|c|}{$\operatorname{PIG}\left(\mathrm{Mg} \mathrm{ha}^{-1}\right)$} \\
\hline & Season 1 & Season 2 & Season 1 & Season 2 & Season 1 & Season 2 \\
\hline \multicolumn{7}{|c|}{ Cowpea cultivars in intercrop } \\
\hline BRS Tumucumaque & $19.78 \mathrm{bA}$ & $21.24 \mathrm{aA}$ & $2.31 \mathrm{aA}$ & $2.18 \mathrm{aA}$ & $0.94 \mathrm{bA}$ & $2.10 \mathrm{aA} *$ \\
\hline BRS Cauamé & $18.83 \mathrm{bA}$ & $21.40 \mathrm{aA}$ & $1.15 \mathrm{bA}$ & $2.08 \mathrm{aA}$ & $0.44 \mathrm{bA}$ & $1.82 \mathrm{aA}$ \\
\hline BRS Guariba & $18.47 \mathrm{bA}$ & $19.99 \mathrm{aA}$ & $1.84 \mathrm{aA}$ & $1.99 \mathrm{aA}$ & $0.75 \mathrm{bA}$ & $1.80 \mathrm{aA}$ \\
\hline BRS Itaim & $15.95 \mathrm{aB}$ & $16.52 \mathrm{aB}$ & $0.60 \mathrm{bB}$ & $1.69 \mathrm{aB}$ & $0.20 \mathrm{bB}$ & $1.47 \mathrm{aB}$ \\
\hline \multicolumn{7}{|c|}{ Radish cultivars in intercrop } \\
\hline Crimson Gigante & \multicolumn{2}{|c|}{$19.09 \mathrm{~A}$} & \multicolumn{2}{|c|}{$1.72 \mathrm{~A}$} & \multicolumn{2}{|c|}{$1.32 \mathrm{~A}$} \\
\hline Zapp & \multicolumn{2}{|c|}{$18.95 \mathrm{~A}$} & \multicolumn{2}{|c|}{$1.61 \mathrm{~A}$} & \multicolumn{2}{|c|}{$1.29 \mathrm{~A}$} \\
\hline \multicolumn{7}{|l|}{ Cropping systems } \\
\hline Intercropping & \multicolumn{2}{|c|}{$19.02 \mathrm{~B}$} & $1.47 \mathrm{bB}$ & $2.26 \mathrm{aB}$ & $0.58 \mathrm{bB}$ & $2.02 \mathrm{aB}$ \\
\hline Monoculture & \multicolumn{2}{|c|}{$19.95 \mathrm{~A}$} & $2.84 \mathrm{aA}$ & $2.64 \mathrm{aA}$ & $1.16 \mathrm{bA}$ & $2.29 \mathrm{aA}$ \\
\hline \multicolumn{7}{|l|}{ Cowpea monoculture } \\
\hline BRS Tumucumaque & \multicolumn{2}{|c|}{$21.13 \mathrm{~A}$} & $3.58 \mathrm{aA}$ & $2.88 \mathrm{aA}$ & \multicolumn{2}{|c|}{$2.36 \mathrm{~A}$} \\
\hline BRS Cauamé & \multicolumn{2}{|c|}{$22.12 \mathrm{~A}$} & $3.96 \mathrm{bA}$ & $2.87 \mathrm{aA}$ & \multicolumn{2}{|c|}{$2.46 \mathrm{~A}$} \\
\hline BRS Guariba & \multicolumn{2}{|c|}{$19.40 \mathrm{~B}$} & $2.30 \mathrm{aB}$ & $2.51 \mathrm{aA}$ & \multicolumn{2}{|c|}{$1.83 \mathrm{~B}$} \\
\hline BRS Itaim & \multicolumn{2}{|c|}{$17.15 \mathrm{C}$} & $1.52 \mathrm{aB}$ & $2.11 \mathrm{aB}$ & \multicolumn{2}{|c|}{$1.65 \mathrm{~B}$} \\
\hline
\end{tabular}

${ }^{(1)}$ Means followed by equal letters, lowercases in the lines and uppercases in the columns, do not differ by Tukey's test, at 5\% probability. 
seasons within each cowpea cultivar in intercrop, the 2017 cropping season showed better values for these variables than in 2016, except for the immature pod length within BRS Itaim, and for the productivity of immature pods within BRS Tumucumaque and BRS Guariba cowpea cultivars that showed similar values.

These interactions are associated with the intra and interspecific competition of cowpea cultivars intercropped with radish cultivars in the cropping seasons, with special emphasis on the 2017 cropping season. Another factor that may justify these interactions is the efficiency in the use of environmental resources reflected in gains for this characteristics in cowpea. In general, the semi-erect cowpea cultivars BRS Tumucumaque, BRS Cauamé, and BRS Guariba - showed better results than BRS Itaim (erect cultivar) for immature pods and grain productivity.

Intercropped cowpea cultivars within each cropping season differed for immature pod length and productivity of immature pods and grains, and BRS Tumucumaque, BRS Cauamé, and BRS Guariba showed higher values than BRS Itaim (Table 2). These different performances express the adaptability of each cowpea cultivar and are directly linked to the pre-established chemical conditions, climatic conditions of each season, and the intercropping with the different radish cultivars. These results agree with those obtained by Costa et al. (2017), who studied these same cowpea cultivars intercropped with carrots and observed that the semi-erect cowpea cultivars performed better than the erect cultivar.

Significant differences between 2017 and 2016 cropping seasons were observed for immature grain yield in both cropping systems, and for the productivity of immature pods only in the intercropping system (Table 2). The monoculture system was superior to the intercropping one for all evaluated cowpea characteristics. These results are consistent with the behavior observed in the radish cultivars, which performed better under the cropping season conditions in 2017 than those in 2016.

A significant difference for the productivity of immature pods was also observed between the cropping seasons, only for BRS Cauamé cowpea cultivar in monoculture, whose result of the 2017 cropping season was higher than that of 2016 (Table 2). This means that in a more adverse situation, as that of 2016, BRS Cauamé was not responsive to the biotic and abiotic factors, considering that the other cultivars did not show statistical difference.

However, in the 2016 cropping season, significant differences between cowpea cultivars in monoculture were also observed for the productivity of immature pods, and BRS Tumucumaque and BRS Cauamé showed better results than the other cultivars; in the 2017 cropping season, for the same parameter, BRS Tumucumaque, BRS Cauamé, and BRS Guariba showed better values than BRS Itaim (Table 2). These results led us to infer that the BRS Tumucumaque, BRS Cauamé, and BRS Guariba cowpea cultivars showed a greater adaptability when exposed to Brazilian Northeast soil and climate conditions.

BRS Tumucumaque and BRS Cauamé in monoculture were better than the other cowpea cultivars for the length of immature pods and for the productivity of immature grains (Table 2). In general, the semi-erect cultivars BRS Tumucumaque, BRS Cauamé, and BRS Guariba produced more immature pods and grains than BRS Itaim.

There was no significant differences between the radish cultivars in intercrop, for none of the evaluated characteristics of cowpea.

The analysis of the interaction between cropping seasons and cowpea cultivars both in the intercrop and monoculture systems shows a different behavior of the cultivars between cropping seasons (Table 2). In the intercrop system, BRS Tumucumaque, BRS Cauamé, and BRS Guariba cultivars showed better results than BRS Itaim for all cowpea characteristics evaluated, and in the monoculture system, only BRS Tumucumaque and BRS Cauamé were better than the other cultivars for the productivity of immature pods. Therefore, the same material does not always perform similarly between cropping systems.

Concerning the influence of cropping seasons on the yield of immature pods, BRS Tumucumaque, BRS Guariba, BRS Cauamé, and BRS Itaim cultivars intercropped with radish showed 69.5, 47.3, 69.2, and $59.6 \%$ for the productivity of immature pods in the monoculture system. The cropping seasons also influence cowpea immature grains, and results for 2017 cropping season were better than those for 2016 . BRS Tumucumaque, BRS Guariba, BRS Cauamé, and BRS Itaim intercropped with radish had 68.6, 52.0, 64.4 and $68.8 \%$ of immature grain yield, when these cultivars were planted in monoculture. The cowpea 
cultivars produced a high percentage of productivity of immature pods and grains, in intercropping, evidencing a good agronomic efficiency of the intercropped system with radish.

The semi-erect cowpea BRS Tumucumaque, BRS Cauamé, and BRS Guariba cultivars produced more immature pods and grains than the erect BRS Itaim (Table 2). These differences can be attributed to the material architecture. Matos Filho et al. (2009) reported that the plant architecture impacts the yield and grain productivity, as well as the use of the environmental resources. Costa et al. (2017) observed that semi-erect cultivars produce more than erect ones.

There were interactions for the system productivity index (SPI) between cropping seasons and radish cultivars, and for the monetary equivalent ratio (MER) between cropping seasons, and radish cultivars and cowpea cultivars of double and triple way (Table 3). There was no significant interaction between production-factors studied in the land equivalent coefficient (LEC).
Partitioning the interaction between cropping seasons, higher productivity indexes of the system were observed in 2017 (Table 3). In turn, the behavior of each radish cultivar within each cropping season showed a higher SPI for the Zapp radish cultivar in 2017, and for the Crimson Gigante radish cultivar in 2016. The main advantage of the SPI is that this index standardizes the productivity of the secondary crop (cowpea) in terms of the main crop (radish).

There were differences among cowpea cultivars according to the SPI, whose highest values were observed for cowpea BRS Tumucumaque and BRS Guariba (Table 3). As to cultivar combinations, the highest SPI values were recorded for the combinations of BRS Guariba cowpea with Crimson Gigante radish, and for BRS Tumucumaque cowpea with Crimson Gigante radish.

Significant differences were observed between the cropping seasons for the land equivalent coefficient (LEC), whose mean values were higher in 2017 than in 2016 (Table 3). However, there were no differences

Table 3. Mean values for system productive index (SPI), land equivalent coefficient (LEC), and monetary equivalent ratio (MER) of cowpea (Vigna unguiculata) intercropped with radish (Raphanus sativus), in 2016 and 2017 cropping seasons, in the different combinations of cowpea and radish cultivars ${ }^{(1)}$.

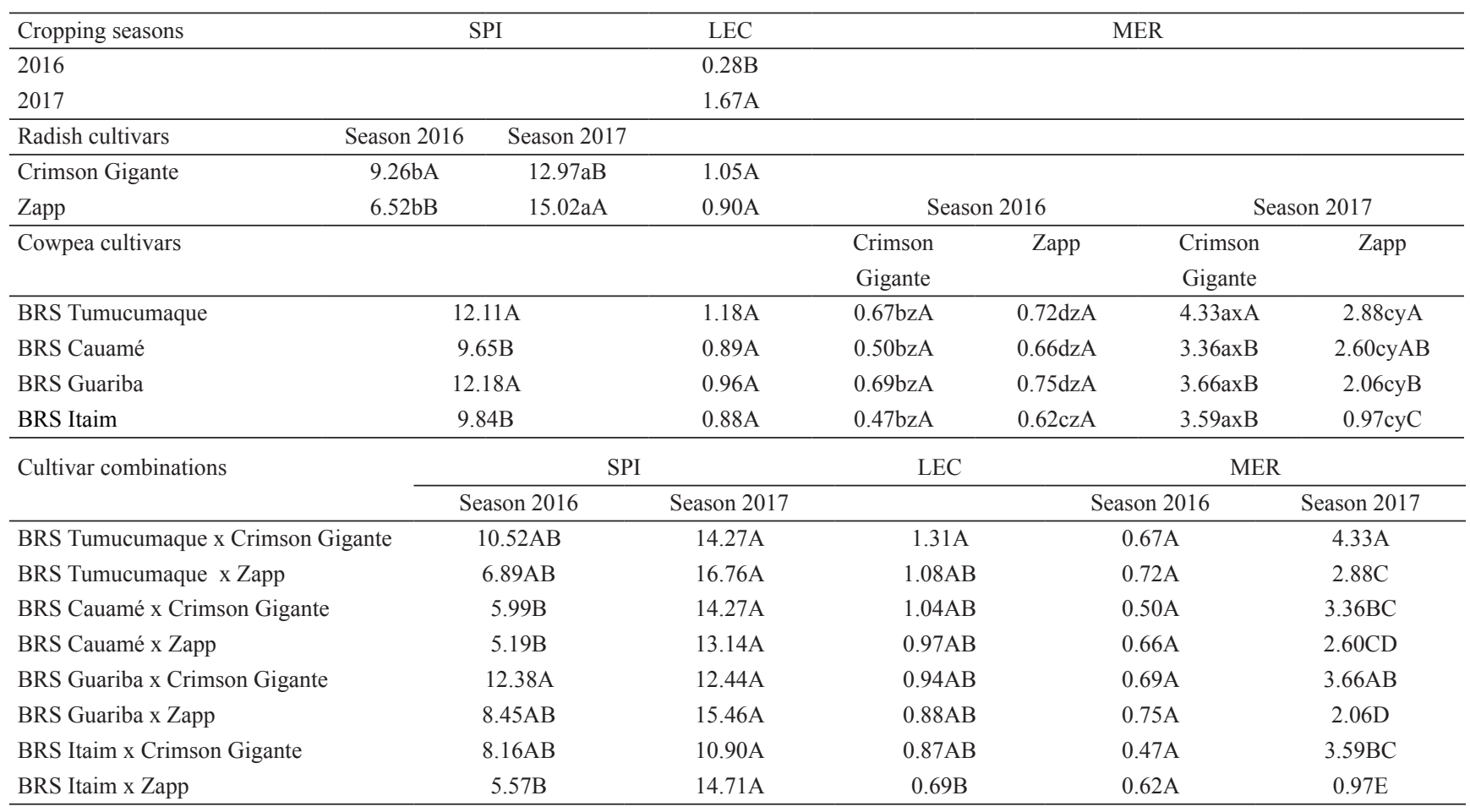

${ }^{(1)}$ Means followed by equal letters, lowercases in the lines and uppercases in the columns, do not differ by Tukey's test, at 5\% probability. 
for LEC mean values between radish and cowpea cultivars.

Partitioning the higher order interaction for MER, that is, the triple interaction between radish cultivars and cowpea cultivars within each cropping season, higher MER values in the combinations of radish and cowpea cultivars were observed in the 2017 cropping season; and, within this season, the highest MER value was observed in the combination of BRS Tumucumaque and BRS Guariba cowpea cultivars with Crimson Gigante radish cultivar (Table 3).

Evaluating combinations of cowpea cultivars with carrot cultivars in a semi-arid environment, Costa et al. (2017) observed that the intercropped system for the association of BRS Guariba cowpea with Alvorada carrot showed a greater agronomic-biological efficiency, while the association of BRS Tumucumaque cowpea with Brasília carrot achieved greater economic efficiency; thus, the best compatibility among the materials was obtained with the combinations of these cultivars. Therefore, our results corroborate those by Costa et al. (2017) for the best compatibility among the cultivars with the combinations of both BRS Guariba and BRS Tumucumaque cowpea with Crimson Gigante radish.

Depending on the component crops, yield advantages can vary considerably due to several factors, including differences of plant architecture, rooting patterns, competitive advantages, and the capacity of potential nitrogen fixation, when a component is a legume. In the present work, there are two species with different rooting architecture and patterns, which can offer competitive advantages and better use of the environmental resources available to the growth and development of the species in the association.

The SPI values obtained in the cropping seasons and in the cultivar combinations of radish and cowpea were superior to those of radish in monoculture, indicating that the best intercropped systems came from the cultivar combinations BRS Guariba cowpea with Crimson Gigante radish and BRS Tumucumaque cowpea with Crimson Gigante radish.

As to LEC, values greater than 0.25 were recorded for all combinations of cowpea and radish cultivars, which means that the yield advantage of the intercropped cultures in relation to their monoculture systems. The highest values of LEC were obtained with the cultivar combinations of BRS Tumucumaque cowpea and Crimson Gigante radish, and BRS Tumucumaque cowpea and Zapp radish.

Values of MER greater than 1 (unit) were recorded for almost all combinations of the cowpea and radish cultivars over the cropping seasons, which indicates the economic superiority of the intercropped system in relation to the monoculture, with the highest economic expression of the radish culture. The cultivar combinations with the highest values of MER (greater than 1) were those of BRS Tumucumaque cowpea with Crimson Gigante radish and BRS Guariba cowpea with Crimson Gigante radish.

\section{Conclusions}

1. The highest productivity of immature pods is obtained with BRS Tumucumaque and BRS Guariba cowpea (Vigna unguiculata) cultivars.

2. The highest yield of radish (Raphanus sativus) commercial roots is obtained with the Crimson Gigante cultivar.

3. The intercrop of BRS Tumucumaque or BRS Guariba cowpea with Crimson Gigante radish cultivars provides greater agro-economy efficiency and sustainability of immature cowpea-radish intercropping.

4. Cowpea and radish intercropping is feasible for agronomic and economic efficiency and sustainability.

\section{Acknowledgments}

To Conselho Nacional de Desenvolvimento Científico e Tecnológico (CNPq), for the financial support (Process no. 474610/2013-6).

\section{References}

ADEKUNLE, Y.A.; OLOWE, V.I.; OLASANTAN, F.O.; OKELEYE, K.A.; ADETILOYE, P.O.; ODEDINA, J.N. Mixture productivity of cassava-based cropping system and food security under humid tropical conditions. Food and Energy Security, v.3, p.46-60, 2014. DOI: https://doi.org/10.1002/fes3.46.

AFE, A.I.; ATANDA, S. Percentage yield difference, an index for evaluating intercropping efficiency. American Journal of Experimental Agriculture, v.5, p.459-465, 2015. DOI: https://doi.org/10.9734/AJEA/2015/12405.

ALVARES, C.A.; STAPE, J.L.; SENTELHAS, P.C.; GONÇALVES, J.L. de M.; SPAROVEK, G. Koppen's climate classification map for Brazil. Meteorologische Zeitschrift, 
v.22, p.711-728, 2013. DOI: https://doi.org/10.1127/09412948/2013/0507.

AZEVEDO, I.B.S. Associações de cultivares de caupi-hortaliça com cultivares de rabanete adubadas com flor-de-seda. 2018. 72p. Dissertação (Mestrado) - Universidade Federal Rural do Semi-Árido, Mossoró.

BATISTA, M.A.V.; BEZERRA NETO, F.; AMBROSIO, M.M.Q.; GUIMARÃES, L.M.S.; SARAIVA, J.P.B.; SILVA, M.L. da. Atributos microbiológicos do solo e produtividade de rabanete influenciados pelo uso de espécies espontâneas. Horticultura Brasileira, v.31, p.587-594, 2013. DOI: https://doi.org/10.1590/ S0102-05362013000400013.

BEZERRA NETO, F.; SILVA, M.L. da; LIMA, J.S.S. de; BARROS JÚNIOR, A.P.; SILVA, I.N.; CHAVES, A.P. Productive viability and profitability of carrot-cowpea intercropping using different amounts of Calotropis procera. Revista Caatinga, v.32, p.62-71, 2019. DOI: https://doi.org/10.1590/1983-21252019v32n107rc.

CHAVES, A.P.; BEZERRA NETO, F.; LIMA, J.S.S.; SILVA, J.N.; NUNES, R.L.C.; BARROS JÚNIOR, A.P.; LIMA, G.K.L.; SANTOS, E.C. Cowpea and beet intercropping agro-economic dynamics under spatial arrangement and cowpea population density. Horticultura Brasileira, v.38, p.192-203, 2020. DOI: https://doi.org/10.1590/s0102-053620200212.

COSTA, A.P. da; BEZERRA NETO, F.; SILVA, M.L. da; LIMA, J.S.S. de; BARROS JÚNIOR, A.P.; PORTO, V.C.N. Intercropping of carrot $x$ cowpea-vegetables: evaluation of cultivar combinations fertilized with roostertree. Revista Caatinga, v.30, p.633-641, 2017. DOI: https://doi.org/10.1590/198321252017v30n311rc.

DAMASCENO, A.S.V.; MASSAROTO, J.A.; NASCIMENTO JUNIOR, A.P. do; MUNHOZ, E.M. Avaliação da produção de alface e rabanete em consórcio. Revista de Ciências Agroambientais, v.14, p.76-81, 2016. Available at: <https:// www.researchgate.net/publication/307852760_Evaluation_of_ production_of_lettuce_and_radish_in_consortium $>$. Accessed on: Dec. 82020.

DOUBI, B.T.S.; KOUASSI, K.I.; KOUAKOU, K.L.; KOFFI, K.K.; BAUDOIN, J.-P.; ZORO, B.I.A. Existing competitive indices in the intercropping system of Manihot esculenta Crantz and Lagenaria siceraria (Molina) Standley. Journal of Plant Interactions, v.11, p.178-185, 2016. DOI: https://doi.org/10.1080/ 17429145.2016.1266042.

FAVACHO, F.S.; LIMA, J.S.S. de; BEZERRA NETO, F.; SILVA, J.N. da; BARROS JÚNIOR, A.P. Productive and economic efficiency of carrot intercropped with cowpea vegetable resulting from green manure and different spatial arrangements. Revista Ciência Agronômica, v.48, p.337-346, 2017. DOI: https://doi.org/10.5935/1806-6690.20170039.

FERREIRA, D.F. Sisvar: a computer statistical analysis system. Ciência e Agrotecnologia, v.35, p.1039-1042, 2011. DOI: https://doi.org/10.1590/S1413-70542011000600001.

GEBRU, H. A review on the comparative advantages of intercropping to mono-cropping system. Journal of Biology, Agriculture and Healthcare, v.5, p.1-13, 2015. Available at: $<$ https://www.semanticscholar.org/paper/A-Review-on-the-
Comparative-Advantage-of-Systems-Gebru/05e21af9ec6c8572cf 2c5d9966bd16fe42176536>. Accessed on: Dec. 82020.

HUNT, N.D.; HILL, J.D.; LIEBMAN, M. Cropping system diversity effects on nutrient discharge, soil erosion, and agronomic performance. Environmental Science and Technology, v.53, p.1344-1352, 2019. DOI: https://doi.org/10.1021/ acs.est.8b02193.

ISLAM, M.M.; KARIM, A.J.M.S.; JAHIRUDDIN, M.; MAJID, N.M.; MIAH, M.G.; AHMED, M.M.; HAKIM, M.A. Effects of organic manure and chemical fertilizers on crops in the radishstem amaranth Indian spinach cropping pattern in homestead area. Australian Journal of Crop Science, v.5, p.1370-1378, 2011.

JARECKI, M.; GRANT, B.; SMITH, W.; DEEN, B.; DRURY, C.; VANDERZAAG, A.; QIAN, B.; YANG, J.; WAGNERRIDDLE, C. Long-term trends in corn yields and soil carbon under diversified crop rotations. Journal of Environmental Quality, v.47, p.635-643, 2018. DOI: https://doi.org/10.2134/ jeq2017.08.0317.

KREMEN, C.; MILES, A. Ecosystem services in biologically diversified versus conventional farming systems: benefits, externalities, and trade-offs. Ecology and Society, v.17, art.40, 2012. DOI: https://doi.org/10.5751/ES-05035-170440.

LINHARES, P.C.F.; SILVA, M.L. da; PEREIRA, M.F.S.; BEZERRA, A.K. de H.; PAIVA, A.C.C. Quantidades e tempos de decomposição da flor-de-seda no desempenho agronômico do rabanete. Revista Verde de Agroecologia e Desenvolvimento Sustentável, v.6, p.168-173, 2011. Available at: <https://www. gvaa.com.br/revista/index.php/RVADS/article/view/631>. Accessed on: Dec. 82020.

MATOS FILHO, C.H.A.; GOMES, R.L.F.; ROCHA, M.M.; FREIRE FILHO, F.R.; LOPES, A.C. de A. Potencial produtivo de progênies de feijão-caupi com arquitetura ereta de planta. Ciência Rural, v.39, p.348-354, 2009. DOI: https://doi.org/10.1590/S010384782009000200006 .

NUNES, R.L.C.; BEZERRA NETO, F.; LIMA, J.S.S.; BARROS JÚNIOR, A.P.; CHAVES, A.P.; SILVA, J.N. Agro-economic responsiveness of radish associations with cowpea in the presence of different amounts of Calotropis procera, spatial arrangements and agricultural crops. Ciência e Agrotecnologia, v.42, p.350363, 2018. DOI: https://doi.org/10.1590/1413-70542018424010318.

OLIVEIRA, E.Q. de; SOUZA, R.J. de; CRUZ, M. do C.M. da; MARQUES, V.B.; FRANÇA, A.C. Produtividade de alface e rúcula, em sistema consorciado, sob adubação orgânica e mineral. Horticultura Brasileira, v.28, p.36-40, 2010. DOI: https://doi.org/10.1590/S0102-05362 010000100007.

OLIVEIRA, G.Q. de; BISCARO, G.A.; MOTOMIYA, A.V. de A.; JESUS, M.P. de; VIEIRA FILHO, P.S. Aspectos produtivos do rabanete em função da adubação nitrogenada com e sem hidrogel. Journal of Agronomic Sciences, v.3, p.89-100, 2014.

PEREIRA, M.F.S.; BEZERRA NETO, F.; PONTES, F.S.T.; LINHARES, P.C.F.; SILVA, M.L. da; SILVA, Í.N. Productive performance of cowpea-radish intercropping under different amounts of rooster tree biomass incorporated into the soil. Revista Brasileira de Engenharia Agrícola e Ambiental, 
v.20, p.965-971, 2016. DOI: https://doi.org/10.1590/1807-1929/ agriambi.v20n11p965-971.

PODDAR, R.; KUNDU; R.; KUMAR, S. Assessment of chickpeaspices intercropping productivity using competitive indices under irrigated conditions of Haryana. Agricultural Research, v.6, p.241-247, 2017. DOI: https://doi.org/10.1007/s40003-017-0260-z.

PORTO, V.C.N.; BEZERRA NETO, F.; LIMA, J.S.S. de; BARROS JÚNIOR, A.P.; MOREIRA, J.N. Combination of lettuce and rocket cultivars in two cultures intercropped with carrots. Horticultura Brasileira, v.29, p.404-411, 2011. DOI: https://doi.org/10.1590/S0102-05362011000300025.

SANTOS, H.G. dos; JACOMINE, P.K.T.; ANJOS, L.H.C. dos; OLIVEIRA, V.Á. de; LUMBRERAS, J.F.; COELHO, M.R.; ALMEIDA, J.A. de; ARAÚJO FILHO, J.C. de; OLIVEIRA, J.B. de; CUNHA, T.J.F. Sistema brasileiro de classificação de solos. 5.ed. rev. e ampl. Brasília: Embrapa, 2018.

SANTOS, H.G. dos; JACOMINE, P.K.T.; ANJOS, L.H.C. dos; OLIVEIRA, V.A. de; LUMBRERAS, J.F.; COELHO, M.R.; ALMEIDA, J.A. de; CUNHA, T.J.F.; OLIVEIRA, J.B. de.
Sistema brasileiro de classificação de solos. 3.ed. rev. e ampl. Brasília: Embrapa, 2013. 353p.

SERAN, T.H.; BRINTHA, I. Review on maize based intercropping. Journal of Agronomy, v.9, p.135-145, 2010. DOI: https://doi.org/10.3923/ja.2010.135.145.

SILVA, J.N. da; BEZERRA NETO, F.; LIMA, J.S.S. de; RODRIGUES, G.S. de O.; BARROS JÚNIOR, A.P.; CHAVES, A.P. Combinations of coriander and salad rocket cultivars in bicropping systems intercropped with carrot cultivars. Revista Caatinga, v.30, p.125-135, 2017. DOI: https://doi. org/10.1590/198321252017v30n114rc.

SILVA-DE LIMA, J.S.; BEZERRA-NETO, F.; ZULEIDE-DE NEGREIRO, M.; CARDOSO-RIBEIRO, M.C.; BARROSJÚNIOR, A.P. Productive performance of carrot and rocket cultivars in strip-intercropping system and sole crops. Agrociencia, v.44, p.561-574, 2010. Available at: <http:// www.scielo.org.mx/scielo.php?script $=$ sci_arttext\&pid $=$ S1405$31952010000500006 \& \operatorname{lng}=$ en $\& n r m=$ iso $>$. Accessed on: Dec. 8 2020. 